\title{
CRITERIA FOR DETERMINING MATURITY STAGE IN FEMALE AMERICAN SHAD, ALOSA SAPIDISSIMA, AND A PROPOSED REPRODUCTIVE CYCLE.
}

\author{
J.E. OLNEY, S.C. DENNY, J.M. HOENIG
}

\begin{abstract}
Department of Fisheries Science, Virginia Institute of Marine Science, College of William and Mary, GLOUCESTER POINT, Virginia, USA 23062.
\end{abstract}

\begin{abstract}
We describe macro- and microscopic criteria to judge maturation stages of female American shad (Alosa sapidissima) collected in the York river, Virginia, USA. For comparison, we also examined ovaries of fishes collected in the Edisto river, South Carolina, and the Connecticut river, Massachusetts. The study augments a developing stock assessment program that is evaluating the use of index-removal and change-in-ratio estimators of exploitation rate and absolute abundance. Samples were obtained from traps at the York river mouth, staked gill nets in mid-reaches of the river, and drift gill nets on the spawning grounds (approximately $100 \mathrm{~km}$ from the river mouth). To judge maturation stages, we used the following macroscopic characters : ovary color, gross appearance of oocytes, degree of blood infusion, and value of the gonosomatic index (ovary weight divided by somatic weight). Stain reactions and presence or absence of cellular characteristics (nucleoli, nuclear migration, oil globules, yolk vesicles, atresia, and postovulatory follicles) were used as microscopic criteria. No differences in scoring of maturation stage were observed in comparisons of samples from different regions of the ovary. American shad in both semelparous (Edisto river) and iteroparous populations (York and Connecticut rivers) exhibit indeterminate fecundity and group-synchronous oocyte development. Unyolked, partially yolked and advanced yolked oocytes are observed in all maturity stages except spent females. There is histological evidence that an individual female spawns in batches over a period of days or weeks since both recently developed and older post-ovulatory follicles are observed simultaneously with advanced yolked oocytes. Most post-spawning females captured at the river mouth are only partially spent with ovaries that contain large numbers of advanced oocytes. A reproductive cycle for American shad in the York river is proposed. Successive or batch spawning in wild populations has important ecological implications since an individual can spread her gametes over a large spatio-temporal scale, thereby increasing the chances that progeny will encounter salubrious conditions.
\end{abstract}

Key-words : maturity stage, ovary, oocyte, post-ovulatory follicle, batch spawning, stock assessment, reproductive cycle. 


\section{CRITÈRES DE DÉTERMINATION DES STADES DE MATURITÉ PARMI LES FEMELLES ALOSA SAPIDISSIMA ET UNE PROPOSITION POUR UN CYCLE DE REPRODUCTION.}

\section{RÉSUMÉ}

Nous décrivons des critères macro et microscopiques pour juger des stades de maturité des aloses américaines femelles (Alosa sapidissima) capturées dans la rivière York, Virginia, USA. A titre de comparaison, nous examinons également des ovaires de poissons capturés dans la rivière Edisto, South Carolina, et dans la rivière Connecticut, Massachusetts. L'étude fait partie d'un programme en cours d'évaluation de stocks, qui utilise la méthode des changements de proportions et de la méthode des changements d'indices d'abondance par prélèvement pour estimer le taux d'exploitation et d'abondance absolue. Des échantillons ont été obtenus grâce à des trappes à l'embouchure de la rivière York, des filets fixes (à mi-parcours migratoire) et des filets dérivants sur les lieux de ponte (à environ $100 \mathrm{~km}$ de l'embouchure). Afin d'établir les stades de maturité, nous avons utilisé les caractères macroscopiques suivants : la couleur des ovaires, l'apparence grossière des ovocytes, le degré d'infiltration sanguin, et l'indice gonosomatique (le poids de l'ovaire divisé par le poids somatique). Des réactions avec les colorants ainsi que la présence ou l'absence de caractéristiques au niveau cellulaire (tels que les nucléoles, la migration nucléaire, les inclusions lipidiques, les vésicules de vitellus, l'atrésie et les follicules post ovulatoires) ont été employées comme critères microscopiques. Nous n'avons observé aucune différence de stade de maturité en comparant les sous échantillons prélevés sur l'ovaire. L'alose américaine semelpare (rivière Edisto) ou les populations itéropares (rivières York et Connecticut) présentent une fécondité indéterminée et un développement d'ovocytes groupe-asynchrome. Des ovocytes prévitellogéniques, partiellement vitellogéniques et des ovocytes avancés ont été observés dans toutes les phases de maturité à l'exception des femelles ayant frayé. II existe des évidences histologiques qui montrent que chaque femelle pond par fraction sur une période de plusieurs jours ou semaines puisque des follicules récemment développés et d'autres, plus âgés, post ovulatoires sont observés simultanément. La plupart des femelles post ovulatoires capturées à l'embouchure de la rivière ont frayé seulement en partie, ayant des ovaires qui contiennent encore un grand nombre d'ovocytes à l'état avancé. Nous avons proposé un cycle de reproduction pour l'alose américaine dans la rivière York. Les pontes multiples dans les populations sauvages d'Alosa ont des implications écologiques importantes puisqu'un poisson peut éparpiller ses gamètes sur une grande période spatio-temporelle et par là augmenter les chances que la progéniture trouvera des conditions salubres.

Mots-clés : stade de maturité, ovaire, ovocyte, follicules post-ovulatoires, pontes successives, programme d'évaluation de stocks, cycle de reproduction.

\section{INTRODUCTION}

The American shad (Alosa sapidissima) is the largest alosine clupeid in North America, attaining a total weight and length of $5.5 \mathrm{~kg}$ and $75 \mathrm{~cm}$, respectively (ROBINS, RAY and DOUGLASS, 1986). The species is native to the western Atlantic Ocean and was introduced to the Pacific coast of North America in 1871 (SCOTT and CROSSMAN, 1973). Each year, adult American shad migrate from mixed population assemblages at sea into the freshwater portions of rivers to spawn (GLEBE and LEGGETT, 1981). Following hatching, young fish reside in the rivers until they reach a size of $7-15 \mathrm{~cm}$ at which point they enter the ocean and remain there until sexual maturity (TALBOT and SYKES, 1958 ; 
NICHOLS and MASSMANN, 1963). Most sexually mature fish return to natal streams to spawn (TALBOT and SYKES, 1958 ; WALBURG, 1960 ; CARSCADEN and LEGGETT, 1975a ; MELVIN, DADSWELL and MARTIN, 1986) and spawning populations constitute genetically distinct assemblages (BENTZEN, BROWN and LEGGETT, 1989 ; NOLAN, GROSSFIELD and WIRGIN, 1991). Along the Atlantic coast of the United States, spawning runs of American shad exist in approximately 193 rivers from the St Johns river, Florida, north to Atlantic Canada (BIGELOW and SCHROEDER, 1953 ; SCOTT and CROSSMAN, 1973 ; RULIFSON, 1994). Along the latitudinal gradient, populations of American shad may be either semelparous in southern rivers from Florida to North Carolina or predominately iteroparous in more northerly rivers (LEGGETT and CARSCADDEN, 1978).

American shad are highly prized for their large ripe ovaries (termed « roe ») and delicate meat that is sold as fresh product. Historically, the species supported large commercial fisheries with landings along the Atlantic coast of approximately 30 million $\mathrm{kg}$ at the turn of the $20^{\text {th }}$ century (WALBURG and NICHOLS, 1967). Since that time, there has been a steady decline in landings (to a recent coast-wide low of only 0.6 million $\mathrm{kg}$ in 1996), and most populations are in serious decline (ASMFC, 1999). Currently, there are approximately 25 separate stocks under federal fisheries management. Many of these stocks are being restored through releases of hatchery-reared larvae and transport of spawning adults to rivers where populations are small or extirpated. Today, there are relatively strong spawning runs (and commercial fisheries) in only a few systems including the Hudson and Connecticut rivers (ASMFC, 1999).

Fisheries for American shad in the York river, Virginia (a tributary in the Chesapeake Bay system) were closed in 1994 following a decade of steady declines in landings. Prior to the closure, the York river supported a large and active fishery using fish traps (pound nets and fyke nets), haul seines, staked gill nets and drift gill nets. Following the moratorium, the status of the York river stock became uncertain in the absence of scientific monitoring. Currently, drift-net fishing by two small native American tribal governments and the taking of brood stock by federal and state agencies for stock restoration is permitted on the spawning grounds. In the former case, tribal landings are unknown but believed to be small since only a few fishermen participate. In the latter case, brood stock are sacrificed for egg taking and the numbers of females killed are recorded (in 1997, 854 females ; 1998, $1610 ; 1999,1417)$.

In the spring of 1998, we initiated a monitoring program to evaluate stock status and began the development of new stock assessment methods (index-removal and change-inratio estimation) that might be useful if the fishery in the river were re-opened (OLNEY and HOENIG, 2001). The components of our developing program are : monitoring catch rate of migrating shad, assessing reproductive condition, and determining the total number of shad caught by sex. The new methods require that the reproductive status (pre-spawning versus post-spawning) of the fish in the samples be known. Index-removal estimation involves examining how an index of abundance changes due to a known selective removal. For example, if the catch-rate of pre-spawning fish in traps at the mouth of a river is 100 and the catch-rate of spent fish is 25, then under the assumption that the catch rate is an index of abundance, we can conclude that three fourths $(75 / 100)$ of the fish have been removed (harvested) upstream or have died due to natural causes. Change-in-ratio estimation involves examining how the sex ratio of pre-spawning fish changes due to a known removal. Since the American shad fishery is selective for large females, the sex ratio of spent fish should reflect fewer females than that of pre-spawning fish. The greater the change in the sex ratio from pre-spawning to spent fish, the higher the exploitation rate. If the harvest is also known, then the size of the run can also be estimated. These methods are described by HOENIG and POLLOCK (1998) and POLLOCK and HOENIG (1998) and have been used by DAWE, HOENIG and XU (1993). 
There are few published studies of ovarian maturation in Alosa. Gross and microscopic descriptions of ovaries and oocytes are presented for the American shad (A. sapidissima) by CLIFT (1872), LEHMAN (1953) and MYLONAS et al. (1995) ; for the anadromous Allis shad ( $A$. alosa) in the Garonne river by BENGEN, KUGLER and PEQUIGNOT (1991) ; and for freshwater populations of the Moroccan shad ( $A$. alosa) by LAHAYE (1960). The ovaries of mature, pre-spawning Alosa spp. contain large numbers of oocytes of various sizes ranging from 0.2-1.8 mm (MYLONAS et al., 1995 ; BENGEN, KUGLER and PEQUIGNOT, 1991). Oocyte ultrastructure and development in Alosa are typical of other clupeiform fishes (HUNTER and MACIEWICZ, 1985) and most teleostean fishes (WALLACE and SELMAN, 1981). The ovaries of mature Alosa contain unyolked, partially yolked, and yolked oocytes (following the terminology suggested by HUNTER and MACIEWICZ, 1985). MYLONAS et al. (1995) did not sample on the spawning grounds and did not observe hydrated oocytes. LAHAYE (1960, her Figure 7) illustrated post-ovulatory follicles in $A$. alosa. BENGEN, KUGLER and PEQUIGNOT (1991) observed swollen oocytes in spawning $A$. alosa females and noted that mature oocytes were located along the dorsal midline of each ovary.

Based on ovarian morphology and oocyte size distribution in captive specimens, MYLONAS et al. (1995) concluded that American shad exhibit asynchronous ovarian development. The authors induced American shad to spawn in the laboratory with continual hormonal treatments, collected eggs daily over a 16-d period, and noted that spawning of treated fish followed a four-day cycle (two days of spawning with high fecundity followed by two days of no spawns or spawns with very low fecundity). There are no studies of spawning frequency or duration for wild American shad and no detailed descriptions of maturity stages based on histological criteria. It is unknown if wild populations of American shad throughout their range exhibit asynchronous ovarian development. These aspects of the reproductive biology of American shad are important for two reasons. Estimates of total fecundity in multiple spawners are the product of batch fecundity and spawning frequency. Thus, detailed information on reproductive activity is required. Also, mis-classifications of maturity stage could bias estimates of pre-spawning and post-spawning fish in index-removal and change-in-ratio estimation of exploitation rate and population size. It is necessary to accurately determine ovarian maturity stage in order to separate the catch into pre-spawning and post-spawning fish.

The objective of this paper is to describe the classification scheme that we are using to assess maturity stage in female American shad, and to present some new data on spawning frequency and batch fecundity. In the process of estimating spawning frequency, we noted some potential methodological problems and discuss these in the context of the available information on American shad reproduction. We also noted that many females are partially spent when they leave the river. We discuss the possible significance of this unexpected observation and propose a reproductive cycle for American shad that incorporates this information.

\section{MATERIALS AND METHODS}

\section{Study area and biological data}

Adult female American shad were collected in the York river system, a coastal plain estuary that flows into in the Chesapeake Bay, and is formed by the confluence of the Pamunkey and Mattaponi rivers at West Point, Virginia, USA (Figure 1). The Pamunkey and Mattaponi watersheds drain approximately $6000 \mathrm{~km}^{2}$, are unimpeded by dams or obstructions, and have average spring discharge rates of 47.5 and $27.2 \mathrm{~m}^{3} . \mathrm{s}^{-1}$, respectively (BILKOVIC, OLNEY and HERSHNER, in press). A total of 306 females were examined in our reproductive analysis during February-June each year from 1998-2000. Total weight, fork length (FL) and total length (TL) of these specimens ranged from : $0.5-2.4 \mathrm{~kg}$; 
34.4-57.5 cm FL ; and 42.4-64.2 cm TL, respectively. Samples were obtained from commercial fish traps at the mouth of the York river, staked gill nets in middle reaches of the river (approximately $24 \mathrm{~km}$ upstream of the river mouth), and drift gill nets on the spawning grounds in both the Mattaponi and Pamunkey rivers (approximately $96 \mathrm{~km}$ upstream of the York river mouth). Specimens were processed in the laboratory and total weight $( \pm 1 \mathrm{~g})$, fork length $( \pm 1 \mathrm{~mm})$, and total length $( \pm 1 \mathrm{~mm})$ were recorded. The paired ovaries were removed, classified into maturity stage macroscopically, weighed $( \pm 0.1 \mathrm{~g})$ and fixed in $10 \%$ formalin. A gonosomatic index (the percent of somatic weight that is gonad weight ; GSI) was calculated for each specimen $(\mathrm{GSI}=$ gonad weight/somatic weight $\times 100)$. For comparative purposes, we also examined ovarian tissue from six specimens collected in the Edisto river near Jacksonboro, South Carolina, in March 1999, and 30 specimens collected in the Connecticut river at the Holyoke Fish Lift, Holyoke, Massachusetts, in May-June 2000. Populations of American shad in the Edisto river are semeparous while those in the York and Connecticut rivers are iteroparous (LEGGETT and CARSCADDEN, 1978 ; ASMFC, 1999).

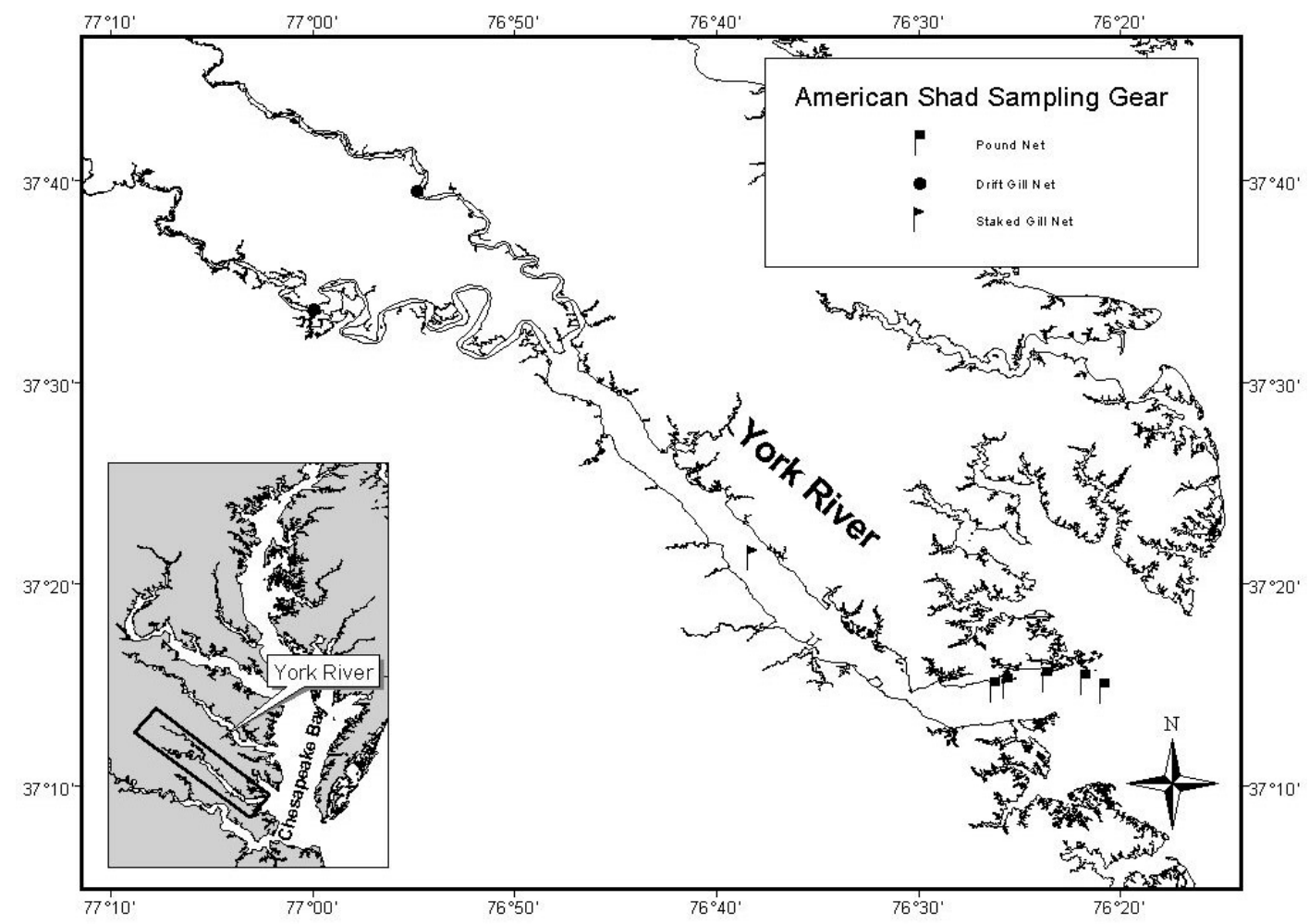

Figure 1

Sampling locations in the York river, Virginia.

Figure 1

Stations d'échantillonnage sur la rivière York, Virginia. 


\section{Histological analysis}

The fixed ovaries were washed, and a small subsample was dissected from anterior, middle and posterior regions of each ovary. The subsamples were weighed, soaked in fresh water for $24 \mathrm{~h}$ and stored in $70 \%$ ethanol. Samples were embedded in paraffin, sectioned to 5-6 $\mu \mathrm{m}$ thickness, placed on clear glass slides, and stained with Harris' hematoxylin and eosin. Stain reactions and presence or absence of cellular characteristics (nucleoli, nuclear migration, oil globules, yolk vesicles, atresia, and postovulatory follicles) were used as microscopic criteria. HUNTER and MACEWICZ (1985) combined the terminology applied to oocyte development of previous authors into a simpler histological classification system, and we utilized these terms (unyolked, partially yolked, yolked and hydrated) in our classification. We noted varying forms of postovulatory follicles (POFs), and assigned approximate ages to each using descriptions provided for POFs of the northern anchovy (Engraulis mordax) following HUNTER and MACEWICZ (1985).

\section{Ovocyte size frequency and batch fecundity}

Fresh (unpreserved) oocytes were washed from subsamples of ovarian tissue following the methods of LOWERRE-BARBIERI and BARBIERI (1993). Two subsamples were randomly chosen from an eight-section grid that encompassed right and left ovarian lobes. Separated oocytes were fixed and preserved in $2 \%$ buffered formalin for at least five days. Oocytes were examined from one half of the subsample that had been divided using a Folsom plankton splitter. The first 200 oocytes were measured using a digital imaging system interfaced with a stereo microscope. Oocytes were measured across the minor axis if they had an oblong shape. The total number of oocytes $>1.6 \mathrm{~mm}$ (mostly hydrated oocytes) in each subsample was counted and then expanded to a total number of oocytes per kg somatic weight by the gravimetric method. The two estimates from each subsample for each specimen were averaged to estimate batch fecundity.

\section{Spawning frequency}

From March through May of 1999, adult female American shad were captured in drift gill nets on the spawning grounds on the Pamunkey river by the Virginia Department of Game and Inland Fisheries as part of a stock enhancement (egg taking, larval rearing and release) program. Each night of sampling (approximately 4:00 PM - 8:00 PM local time), hydrated and running ripe females were captured in drift gill nets and sacrificed for egg taking ; the remaining non-spawning females were counted and released. We used these data to estimate spawning frequency following the percent-hydrated method of DEMARTINI and FOUNTAIN (1981) and HUNTER and MACEWICZ (1985).

\section{RESULTS}

In all comparisons, the location of the tissue subsample taken from the ovary had no effect on determination of maturity stage in American shad. Immature American shad were not captured and are not described here.

\section{Microscopic determination of maturity stage}

Maturing (Figure 2-A ; Plates 1-A, 2-A)

Ovaries of maturing American shad contain unyolked (purple stain reaction), partially yolked (light purple to red stain reaction), and yolked oocytes (deep red stain reaction) that range in size from $0.4 \mathrm{~mm}-1.7 \mathrm{~mm}$. The smallest oocytes are excluded in this size distribution since they did not wash out of tissue subsamples, remaining as "oogonial 
nests » (small primary growth cells in tight groups and having no true follicular layer). Oocyte size distributions are uni-modal with most oocytes $<1.6 \mathrm{~mm}$. The largest oocytes are spherical or nearly so. There are only small amounts of blood in tissue samples. Many maturing ovaries contain a small number of atretic oocytes that lack typical cellular organization, have a weak stain reaction, and are non-spherical in shape. In our classification, we combined early, middle and late phases of this pre-spawning stage. The primary differences observed along this continuum of development are those relating to the relative number of yolked oocytes, with the greatest number observed in ovaries that are nearing hydration.

\section{Hydrated / Running Ripe (Figure 2-B, 2-C ; Plates 1-B, 2-B, 2-C)}

Ovaries have unyolked, partially yolked, yolked and hydrated oocytes. The large hydrated oocytes are conspicuous because they stain pink in histological preparations. Just prior to spawning, hydrated oocytes are unovulated and are broadly scattered throughout ovary. In running ripe individuals, oocytes are ovulated (released from the follicular layer) and usually accumulate in a clear tubular area along the dorsal midline of both ovarian lobes. Upon ovulation, the follicular layer (a thin layer of granulosa and thecal cells) is left behind in the ovarian tissue (termed a postovulatory follicle or POF) and is conspicuous. Oocyte size distributions are bi-modal ; the hydrated oocytes are large $(>1.6 \mathrm{~mm})$ and represent a cohort that is distinct from a cohort of smaller-sized oocytes $(<1.6 \mathrm{~mm})$ that does not contain hydrated oocytes. Partially yolked and yolked oocytes in the smaller-sized cohort represent the oocyte pool from which batches of future hydrated oocytes develop. In ovaries that have produced only one or a few batches of hydrated oocytes, the smaller-sized cohort of partially yolked and yolked oocytes is abundant (Figure 2-B) ; with sequential spawning, this pool of oocytes becomes less numerous (Figure 2-C). For convenience, we combined hydrated and running ripe in our classification but these can be distinguished by the presence or absence of POFs.

Partially Spent (Figure 2-D ; Plates 1-C, 1-F, 1-G, 2-D)

Partially spent ovaries have large numbers of POFs (both fresh or older), many blood cells, extensive atresia, and some have remnants of hydrated oocytes that were not spawned. Fresh POFs have distinct, convoluted shapes with many folds, a clear lumen within which scattered granulosa cells are usually observed, a distinct granulosa and thecal layer and little evidence of degeneration (Plate 3-A). In older POFs, the number of folds decreases, the structure is smaller and usually more elongate, and the thecal layer is less distinct (Plates 3-B, 3-C). Partially spent ovaries also have large numbers unyolked, partially yolked and yolked oocytes that range in size from 0.4-1.8 mm. Oocyte size distributions are bimodal but the largest cohort $(>1.6 \mathrm{~mm})$ does not contain unovulated hydrated oocytes and is proportionally less numerous than cohorts with smaller-sizes oocytes.

Spent (Figure 2-E ; Plates 1-D, 2-E)

Spent ovaries have large numbers of POFs, many blood cells, and large areas of degenerated, unorganized tissue (atretic POFs and oocytes that cannot be distinguished). The ratio of fresh to older POFs is $<1$ or there are no fresh POFs visible. Oocytes range in size from $0.1-2.0 \mathrm{~mm}$, and size frequencies are strongly bimodal. There are large numbers of unyolked oocytes $(<0.8 \mathrm{~mm})$. The few partially yolked or yolked oocytes that are present are usually in varying stages of atresia. 

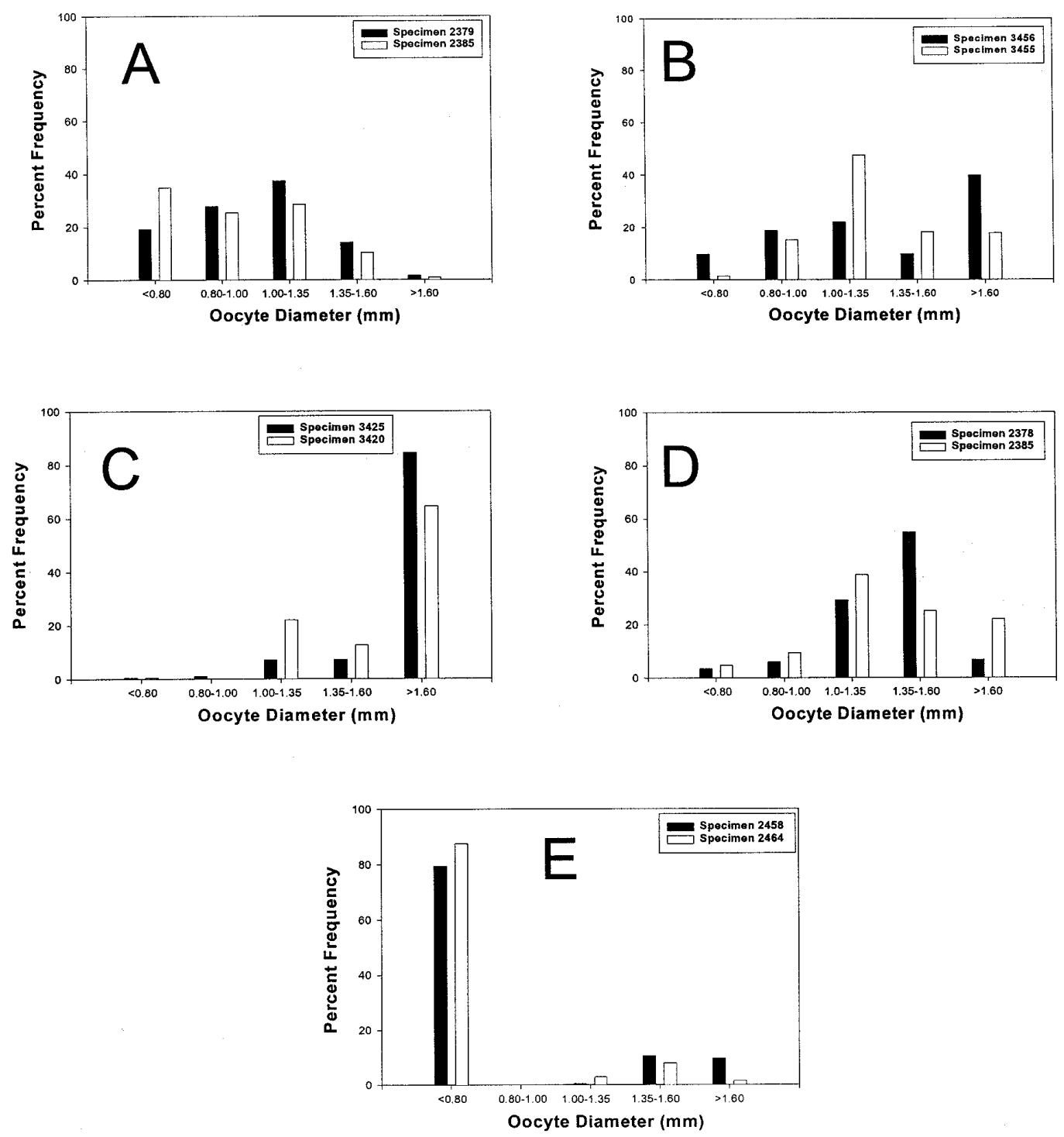

Figure 2

Oocyte size frequency distributions in eight specimens of American shad from the York river, Virginia. A, maturing ; B, hydrated ; C, running ripe ; D, partially spent ; E, spent.

\section{Figure 2}

Distributions de fréquences de tailles d'ovocytes de huit spécimens d'alose américaine provenant de la rivière York, Virginia. A, en voie de maturation ; $B$, hydraté ; $C$, très mûr ; $D$, partiellement frayé ; $E$, frayé.

\section{Resting (Plates 1-E, 2-F)}

Ovaries only have unyolked oocytes. These unyolked oocytes do not wash out of tissue subsamples (thus, we present no size frequency distributions). Macrophage aggregates are visible and there is some blood. There is some evidence of late stage atresia but there are no large areas of unorganised tissue. 

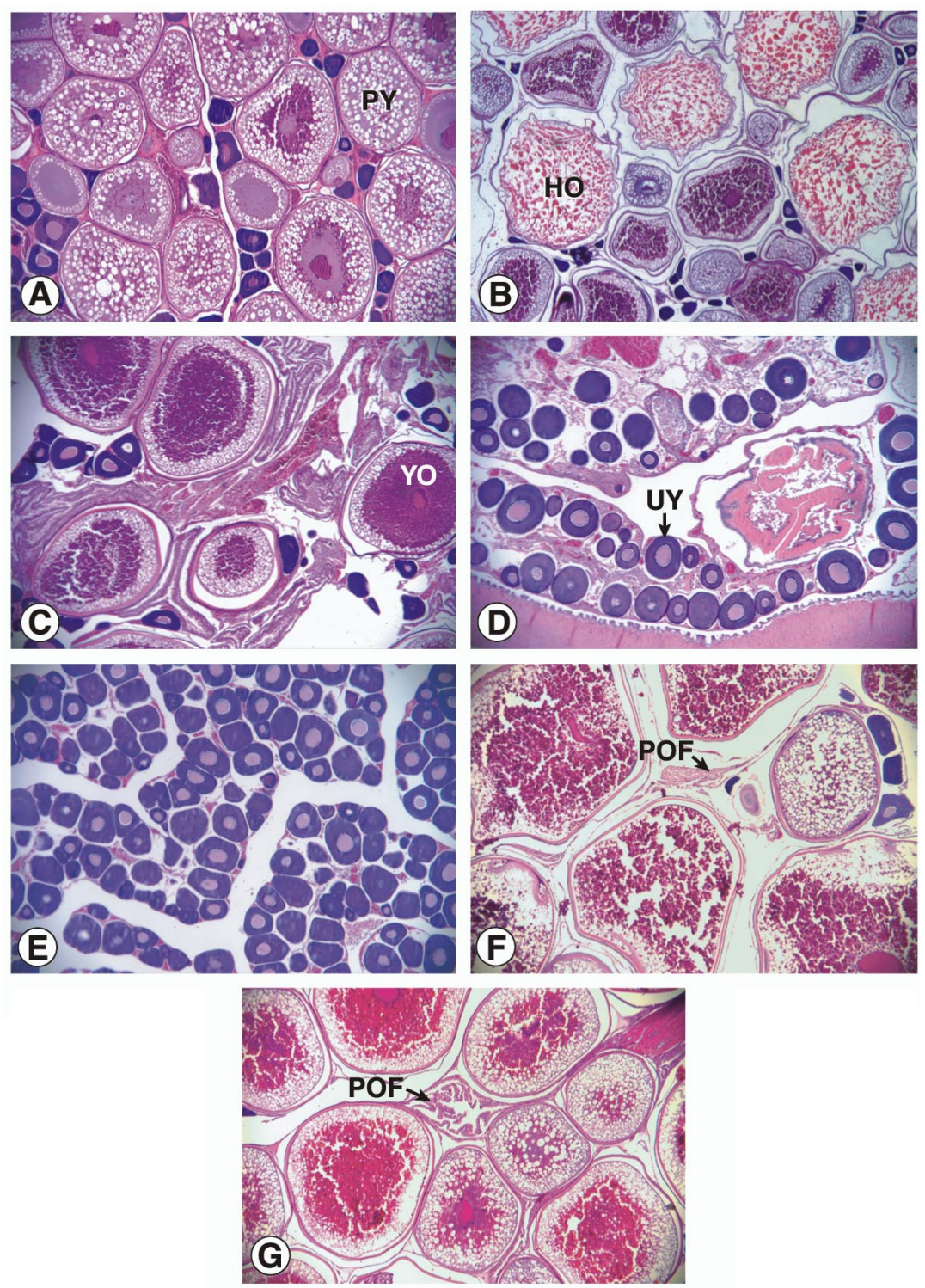

Plate 1

Photomicrographs of sectioned and stained ovarian tissue of American shad at various magnifications from the York river, Virginia (A-E), the Connecticut river, Massachusetts (F) and the Edisto river, South Carolina (G). A, maturing ; $B$, hydrated ; C, partially spent ; D, spent ; $E$, resting ; $F$, partially spent ; G, partially spent. Abbreviations are : UY, unyolked oocyte ; PY, partially yolked oocyte ; YO, advanced yolked oocyte ; POF, postovulatory follicle ; HO, hydrated oocyte.

\section{Planche 1}

Microphotographies à divers grossissement de coupes d'ovaires des aloses américaines, provenant de la rivière York, Virginia $(A-E)$, de la rivière Connecticut, Massachusetts (F) et de la rivière Edisto, South Carolina (G). A, en voie de maturation ; B, hydraté ; C, partiellement frayé ; D, frayé ; $E$, au repos ; F, partiellement frayé ; G, partiellement frayé ; Les abréviations sont : UY, ovocyte prévitellogénique ; $P Y$, ovocyte en cours de vitellogénèse; YO, vitellogénèse ; POF, follicule post-ovulatoire ; HO, ovocyte hydraté. 

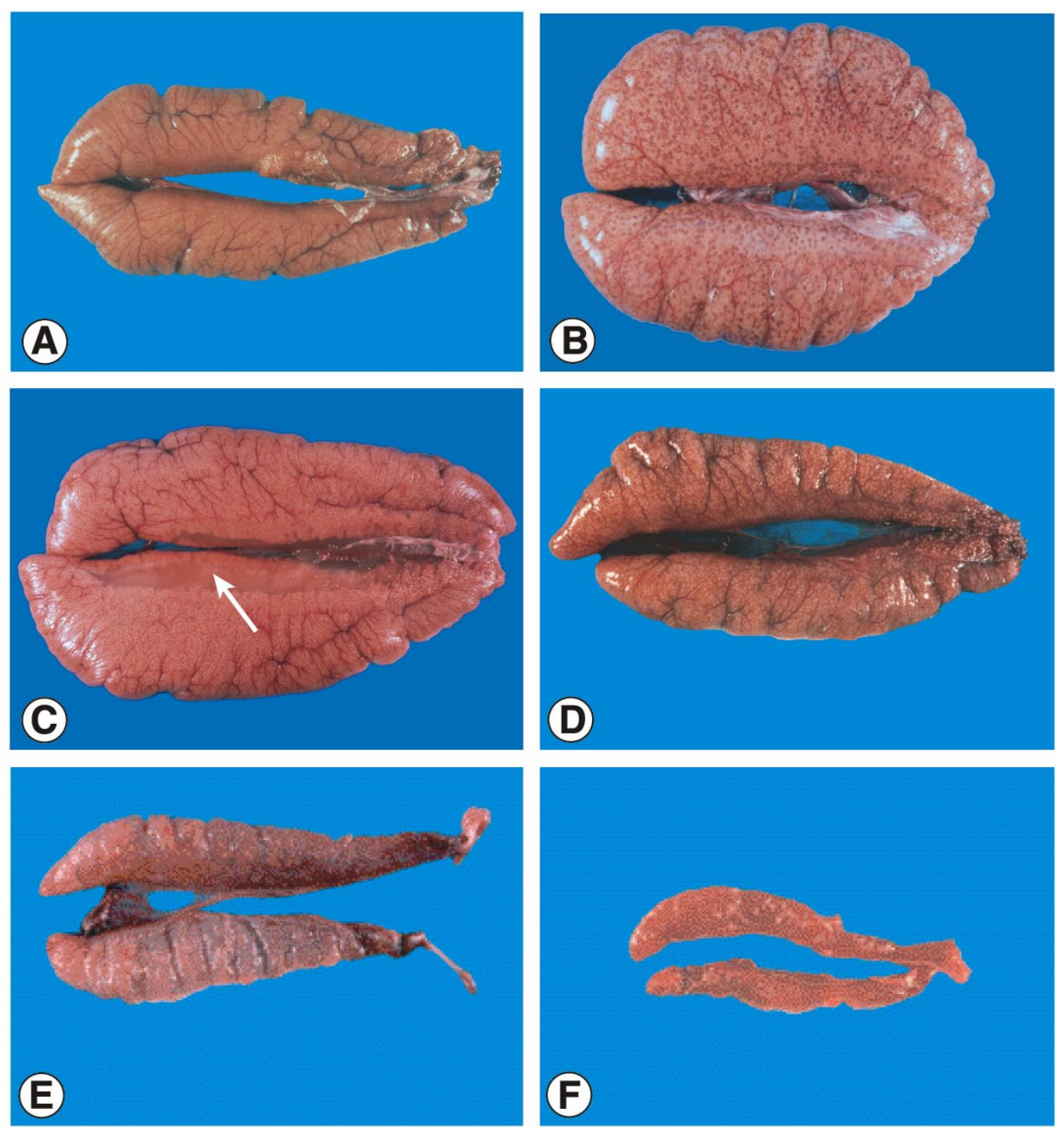

\section{Plate 2}

Whole ovaries of American shad from the York river, Virginia. A, maturing ; $B$, hydrated ; C, running ripe ; D, partially spent ; E, spent ; F, resting. Arrow denotes area of accumulation of hydrated oocytes along the dorsal midline just prior to spawning.

\section{Planche 2}

Ovaires entiers de l'alose américaine provenant de la rivière York, Virginia. A, en voie de maturation ; $B$, hydraté ; $C$, très mûr ; $D$, partiellement hydraté ; $E$, après ponte ; $F$, au repos. La flèche marque la région d'accumulation d'ovocytes hydratés le long de la ligne médiane dorsale, juste avant la ponte. 

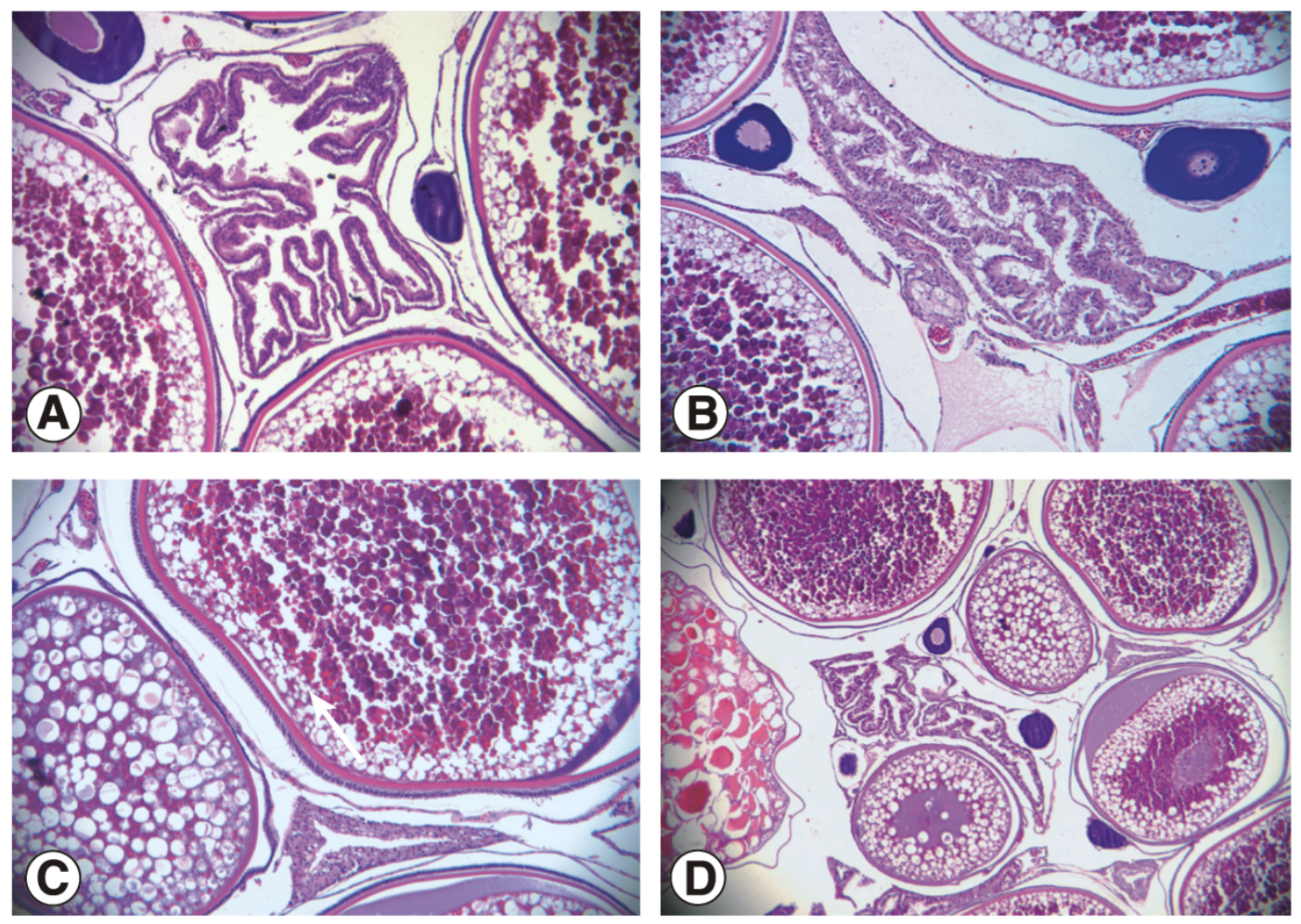

Plate 3

Photomicrographs of postovulatory follicles (POFs) in ovarian tissue of American shad from the York river, Virginia. A, newly evacuated follicle; B-C, older follicles of unknown but increasing age; $D$, same view as $C$ but at lower magnification showing the presence of fresh and older POFs in the same sample.

\section{Planche 3}

Microphotographies des follicules post-ovulatoires (POF) du tissu ovarien de l'alose américaine provenant de la rivière York, Virginia. A, follicule récemment libéré ; B-C, follicule plus ancien, d'âge inconnu mais croissant ; $D$, même vue que $\mathrm{C}$ mais à un faible grossissement montrant la présence de POF à la fois nouveaux et âgés dans le même échantillon.

\section{Macroscopic staging}

To judge maturation stages macroscopically, we used the following gross characters : ovary color (yellow, orange, light red, blood red), ovary condition (firm versus soft and flaccid), ovary size (small, medium, large or very large), appearance and relative number of oocytes viewed through the ovarian wall (few or many ; small or large ; red, yellow or clear), degree of blood infusion (little visible blood, very bloody), and the value of the gonosomatic index. In maturing specimens (Plate 2-A ; GSI, $3.0 \%-24.0 \%$; mean, $11.4 \%$ ), the ovary is large, firm, yellow to bright orange with a few to many yolked oocytes visible through the ovarian wall. In hydrated specimens (Plate 2-B ; GSI, $5.8 \%-35.4 \%$; mean, $20.5 \%$ ), the ovary is very large, firm, red or orange with many clear oocytes visible through the ovarian wall. In running ripe specimens (Plate 2-C), these hydrated oocytes accumulate along the dorsal midline and often spill out of the ovary when it is handled. In partially spent specimens (Plate 2-D ; GSI, $2.1 \%-15.5 \%$; mean, $6.5 \%$ ), the ovary is medium in size, firm (if only one or a few batches were spawned just prior to capture) to 
soft and flaccid (if nearing the terminal batch), more red than orange in color with a few to many yolked oocytes (occasionally, a few hydrated oocytes) visible through the ovarian wall. In spent ovaries, (Plate 2-E ; GSI, $1.3 \%-5.5 \%$; mean, $2.3 \%$ ), the ovary is small to moderate in size, soft and flaccid, dark red to purple with only a few yolked oocytes that are widely scattered. In resting specimens (Plate 2-F ; GSI, $0.7 \%-1.9 \%$; mean, $1.0 \%$ ), the ovary is small, flat and firm, dark red to deep purple with no visible oocytes.

We evaluated the degree to which maturity stage can be accurately determined by macroscopic examination of ovaries by comparing histological results to the corresponding results from gross examination (Table I). Histological evidence was taken as the definitive result in these comparisons. In a total of 302 trials, there were 187 agreements between the methods (61.9\%). Agreement was high for maturing, hydrated and spent fish but low for partially spent and resting stages (Table I). We analyzed these differences with a test of symmetry (HOENIG, MORGAN and BROWN, 1995) to test the hypothesis that the observed error was randomly distributed along the table diagonal (i.e., that the two methods are interchangeable). As expected, the hypothesis was rejected $\left(\chi^{2}=116.5\right.$, degrees of freedom $=8, p<0.0005$ ).

\section{Table I}

Macroscopic and microscopic scoring of maturity stage in a sample of 302 female American shad (Alosa sapidissima) taken in pound nets and drift gill nets in the York river in 1998-1999. Bold numbers are where the two methods agree. Superscripts denote paired comparisons for a $\chi^{2}$ test of symmetry.

\section{Tableau I}

Scores macroscopiques et microscopiques de l'état de maturité dans un échantillon de 302 aloses américaines femelles capturées dans des picqes et des filets maillant dérivants dans la rivière York en 1998-1999. Les chiffres gras représentent les situations où les deux méthodes concordent. Les caractères inscrits au-dessus de la ligne représentent les paires comparées dans un test de symétrie $\chi^{2}$.

MICROSCOPIC CLASSIFICATION

\begin{tabular}{|ll|l|l|l|l|l|l|}
\hline MACROSCOPIC CLASSIFICATION & 1 & 2 & 3 & 4 & 5 & 6 \\
\hline 1 & (immature) & $\mathbf{0}$ & $3^{(0)}$ & & & & $5^{(1)}$ \\
\hline 2 & (maturing) & $0^{(0)}$ & $\mathbf{1 2 6}$ & $3^{(2)}$ & $17^{(3)}$ & $0^{(5)}$ & \\
\hline 3 & (hydrated/running ripe) & & $1^{(2)}$ & $\mathbf{2 4}$ & $4^{(4)}$ & & \\
\hline 4 & (partially spent) & & $1^{(3)}$ & $2^{(4)}$ & $\mathbf{1 3}$ & $1^{(6)}$ & $0^{(8)}$ \\
\hline 5 & (spent) & & $1^{(5)}$ & & $69^{(6)}$ & $\mathbf{2 0}$ & $5^{(7)}$ \\
\hline 6 & (resting) & $0^{(1)}$ & & & $1^{(8)}$ & $1^{(7)}$ & $\mathbf{4}$ \\
\hline Percent Agreement by stage & ---- & $95.5 \%$ & $82.3 \%$ & $12.5 \%$ & $90.9 \%$ & $28.6 \%$ \\
\hline
\end{tabular}

\section{Spawning frequency and batch fecundity}

Brood females with hydrated eggs $(n=1417)$ and non-spawning females ( $n=4121$ ) were captured during 36 nights of sampling from 17 March to 8 May 1999. Hydrated females were first collected on 25 March 1999 when water temperature reached $11^{\circ} \mathrm{C}$. The proportion of the daily catch that was hydrated and running ripe gradually increased during the sampling period and peaked on 5 May 1999 (Table II). Sampling ceased on 8 May when no hydrated females were captured and water temperatures reached $22^{\circ} \mathrm{C}$. To estimate spawning frequency, we ignored collections prior to 
30 March 1999 and on the last day, reasoning that spawning was either just beginning or completed during these days of sampling. In 1999, $28.5 \%$ of all females collected from 31 March to 7 May were running ripe. The resulting estimate was a spawning frequency of 3.5 d (100\% / $28.5 \%)$ using the methods of DEMARTINI and FOUNTAIN (1981) and HUNTER and MACEWICZ (1985).

Table II

Daily catches of female American shad (Alosa sapidissima) in drift gill nets on the spawning grounds of the Pamunkey river, Virginia. These data were provided by T. GUNTER (Virginia Department of Game and Inland Fisheries).

\section{Tableau II}

Captures journalières d'aloses américaines femelles dans des filets dérivants aux lieux de ponte de la rivière Pamunkey, Virginia. Ces données ont été fournies par T. GUNTER (Virginia Department of Game and Inland Fisheries).

\begin{tabular}{|c|c|c|c|}
\hline Date in 1999 & $\begin{array}{c}\text { Number of } \\
\text { hydrated } \\
\text { females }\end{array}$ & $\begin{array}{c}\text { Number of non- } \\
\text { spawning females }\end{array}$ & $\begin{array}{l}\text { Percent (\%) } \\
\text { hydrated }\end{array}$ \\
\hline 16 March & 0 & 1 & 0.0 \\
\hline 19 March & 0 & 80 & 0.0 \\
\hline 23 March & 0 & 76 & 0.0 \\
\hline 25 March & 2 & 104 & 1.9 \\
\hline 27 March & 0 & 70 & 0.0 \\
\hline 28 March & 13 & 173 & 7.0 \\
\hline 29 March & 16 & 221 & 6.8 \\
\hline 30 March & 24 & 235 & 9.3 \\
\hline 31 March & 50 & 202 & 19.8 \\
\hline 1 April & 60 & 200 & 23.1 \\
\hline 2 April & 137 & 218 & 38.6 \\
\hline 3 April & 48 & 210 & 18.6 \\
\hline 4 April & 83 & 170 & 32.8 \\
\hline 5 April & 122 & 144 & 45.9 \\
\hline 6 April & 64 & 234 & 21.5 \\
\hline 7 April & 67 & 130 & 34.0 \\
\hline 8 April & 49 & 191 & 20.4 \\
\hline 10 April & 0 & 13 & 0.0 \\
\hline 11 April & 57 & 110 & 34.1 \\
\hline 13 April & 18 & 61 & 22.8 \\
\hline 14 April & 19 & 65 & 22.6 \\
\hline 15 April & 37 & 159 & 18.9 \\
\hline 16 April & 46 & 167 & 21.6 \\
\hline 17 April & 53 & 84 & 38.7 \\
\hline 21 April & 38 & 82 & 31.7 \\
\hline 22 April & 60 & 133 & 31.1 \\
\hline 23 April & 0 & 55 & 0.0 \\
\hline 24 April & 59 & 128 & 31.6 \\
\hline 25 April & 51 & 61 & 45.5 \\
\hline 26 April & 42 & 57 & 42.4 \\
\hline 29 April & 0 & 56 & 0.0 \\
\hline 4 May & 39 & 54 & 41.9 \\
\hline 5 May & 75 & 66 & 53.2 \\
\hline 6 May & 52 & 59 & 46.8 \\
\hline 7 May & 36 & 44 & 45.0 \\
\hline 8 May & 0 & 8 & 0.0 \\
\hline TOTAL & 1417 & 4121 & \\
\hline
\end{tabular}


Average batch fecundity (the mean number of oocytes $>1.6 \mathrm{~mm}$ per $\mathrm{kg}$ of somatic weight) was estimated for six hydrated/running ripe females and ranged from about 20000 to 70000 (Table III). In the two females with the highest batch fecundity (specimens \# 3455 and \# 3456), the relative numbers of small oocytes (< $1.6 \mathrm{~mm}$ ) were high (Figure 2-B), suggesting that these individuals had produced only one or a few batches of hydrated oocytes prior to capture. In the two females with the lowest batch fecundity (specimens \# 3420 and \# 3425), the relative numbers of small oocytes $(<1.6 \mathrm{~mm})$ were low (Figure 2-C), suggesting that we counted the number of eggs in the terminal batch. Thus, batch fecundity probably decreases with sequential spawning in wild American shad as was observed for captive fish (MYLONAS et al., 1995).

\section{Table III}

Average batch fecundity of female American shad (Alosa sapidissima) collected on the York river (Virginia) and the Connecticut river (Massachusetts). Numbers of oocytes $>1.6 \mathrm{~mm}$ were counted in two subsamples from each specimen and then expanded to the total number of oocytes $/ \mathrm{kg}$ of somatic weight.

\section{Tableau III}

Fécondité moyenne des aloses américaines femelles capturées de la rivière York, Virginia et de la rivière Connecticut, Massachusetts. Le nombre d'ovocytes $>1,6 \mathrm{~mm}$ a été compté dans deux sous-échantillons de chaque spécimen et puis a été étendu pour estimer le nombre total d'ovocytes/kg de poids somatique.

\begin{tabular}{|l|c|c|c|c|c|}
\hline $\begin{array}{c}\text { Specimen number, } \\
\text { total length (TL) }\end{array}$ & $\begin{array}{c}\text { Somatic } \\
\text { Weight }(\mathrm{kg})\end{array}$ & $\begin{array}{c}\text { Gonad } \\
\text { Weight }(\mathrm{g})\end{array}$ & $\begin{array}{c}\text { Subsample } \\
\text { Weights }(\mathrm{g})\end{array}$ & $\begin{array}{c}\text { Number of ova } \\
>1.6 \mathrm{~mm}\end{array}$ & $\begin{array}{c}\text { Average batch } \\
\text { fecundity (ova/kg) }\end{array}$ \\
\hline York River & & & & & \\
\hline$\# 3456,40.3 \mathrm{~cm}$ & 1.0 & 275.7 & $5.3 ; 5.8$ & $912 ; 1446$ & 57914 \\
\hline$\# 3455,42.5 \mathrm{~cm}$ & 1.1 & 309.7 & $5.7 ; 6.4$ & $1524 ; 1560$ & 69887 \\
\hline$\# 3420,44.0 \mathrm{~cm}$ & 0.8 & 101.1 & $5.3 ; 6.7$ & $942 ; 1,062$ & 20226 \\
\hline$\# 3425,42.2 \mathrm{~cm}$ & 1.2 & 188.2 & $6.5 ; 5.8$ & $1150 ; 1314$ & 31592 \\
\hline & & & & & \\
\hline Connecticut River & & & & & \\
\hline \#29, 48.0 cm & 1.6 & 329.8 & $5.6 ; 5.3$ & $1320 ; 1527$ & 55035 \\
\hline$\# 15,49.0 \mathrm{~cm}$ & 1.1 & 326.7 & $5.5 ; 5.6$ & $1208 ; 1368$ & 69213 \\
\hline
\end{tabular}

\section{Spatial and temporal distribution of maturity stages}

The size of the ovary of American shad increases during its spawning migration up the York river system (Figure 3). Mean values of the GSI for pre-spawning (maturing) American shad were about $9 \%$ in pound nets at the river mouth, $14 \%$ in staked gill nets in the middle reaches and about $20 \%$ in drift gill nets when females reached the spawning grounds approximately $100 \mathrm{~km}$ from the river entrance. Post-spawners (partially spent, spent or resting) captured on the down-river migration had smaller ovaries ; mean GSI values were from $4-6 \%$ in staked gill nets and pound nets. At the river mouth, exclusively maturing females were captured in February and early March but maturing females continued to enter the river throughout the season until mid-May (Figure 4). Partially spent females appeared at the river mouth in mid-March ; partially spent, spent and resting females predominated the catch in late April and May. Immature and hydrated/running ripe females were not captured in the pound nets at the river mouth. Surprisingly, a large proportion of the post-spawners $(n=129)$ captured at the river mouth (about $100 \mathrm{~km}$ from the spawning grounds) were partially spent $(68 \%)$. The ovaries of partially spent females were 1-8 times larger than those of spent females (Figure 5). 


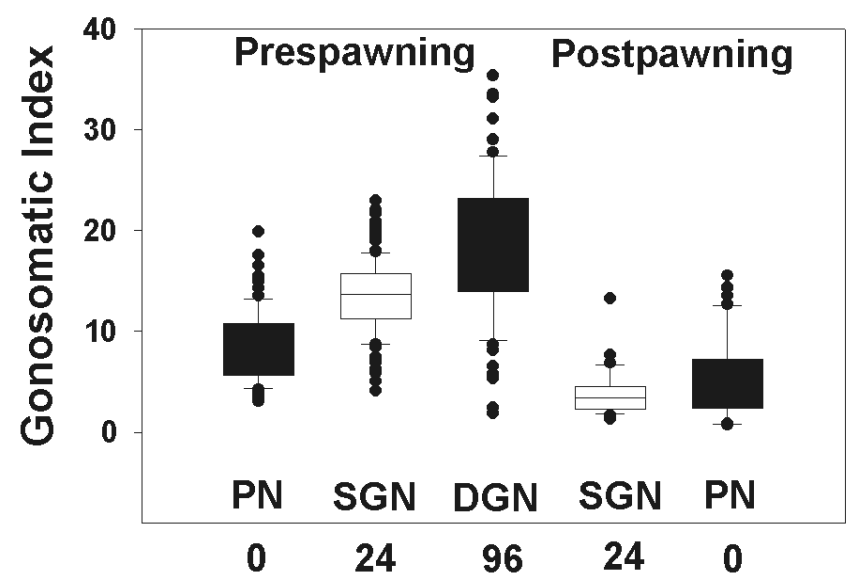

River km and gear

Figure 3

Box diagrams depicting mean, one standard error, $95 \%$ confidence intervals and outliers of the gonosomatic index of pre-spawning and post-spawning American shad captured in pound nets (PN), staked gill nets (SGN) and drifts nets (DGN) in the York river, Virginia.

\section{Figure 3}

Tracés en boîtes représentant la moyenne, l'écart-type, les intervalles de confiance à $95 \%$ et les valeurs aberrantes de l'indice gonosomatique avant et après la ponte des aloses américaines capturées dans des picques, des filets fixes et des filets dérivant dans la rivière York, Virginia.

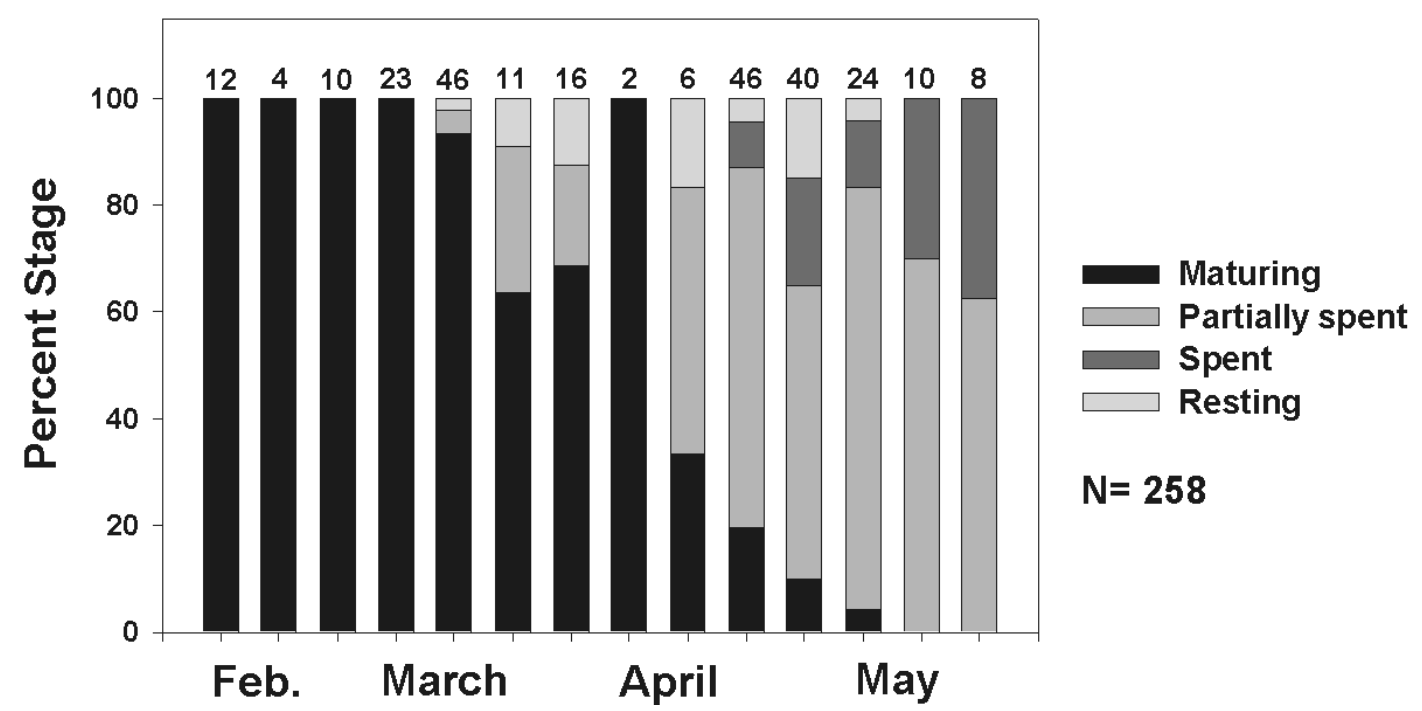

Figure 4

Weekly proportion in each maturity stage of American shad from the York river, Virginia during the spawning runs in 1998-1999. Numbers above bars denote sample size in each week.

\section{Figure 4}

Proportion hebdomadaire de chaque état de maturité de l'alose américaine en provenance de la rivière York, Virginia pendant les migrations de ponte en 19981999. Les chiffres au-dessus des barres indiquent la taille de l'échantillon. 


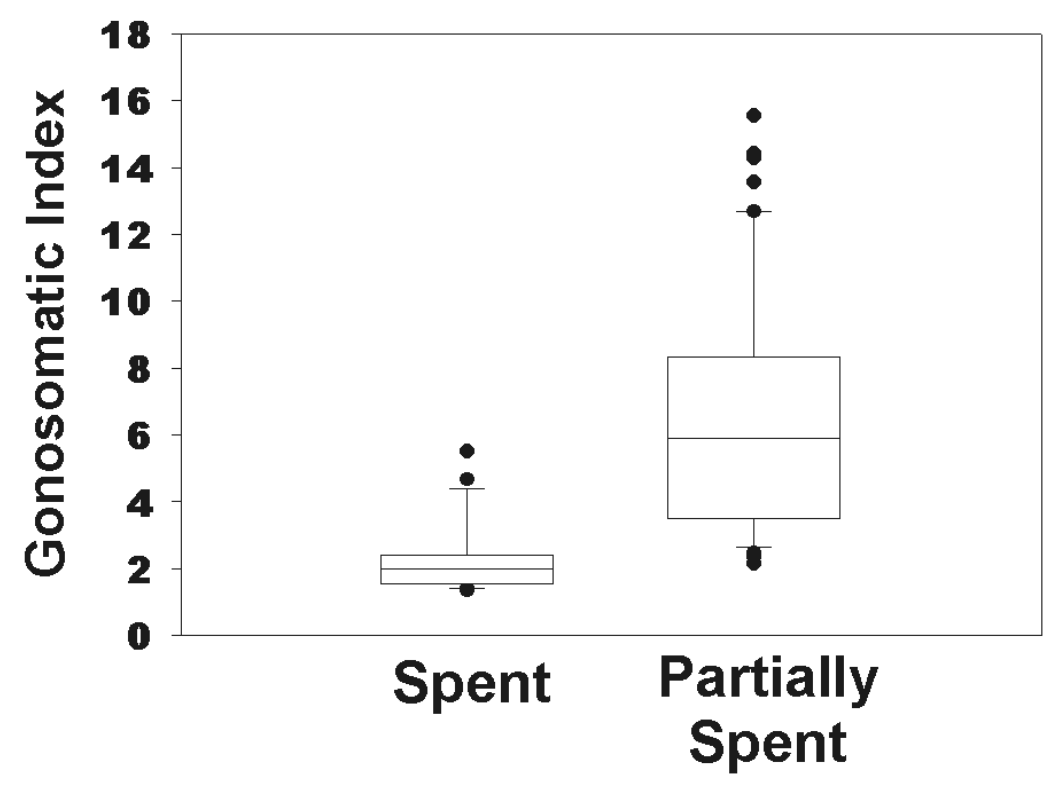

Figure 5

Box diagrams depicting mean, one standard error, $95 \%$ confidence intervals and outliers of the gonosomatic index of spent and partially spent American shad from the York river, Virginia.

\section{Figure 5}

Tracés en boîtes représentant la moyenne, un écart-type, les intervalles de confiance a $95 \%$ et les valeurs aberrantes de l'indice gonosomatique des aloses américaines ayant partiellement et complètement frayé et provenant de la rivière York, Virginia.

\section{DISCUSSION}

Wild American shad in both semelparous and iteroparous populations along the U.S. Atlantic coast exhibit group-synchronous ovarian development and are batch spawners (i.e., an individual female spawns repeatedly during each spawning season). The ovaries of partially spent individuals on spawning grounds in the Edisto river (South Carolina), the York river (Virginia), and the Connecticut river (Massachusetts) contained cohorts of partially yolked and yolked oocytes as well as both fresh and older POFs. The POFs are evidence of previous recent spawns and the developing cohorts represent future batches of oocytes. Our estimates of batch fecundity (20 000-70 000 eggs per kg somatic weight) and spawning frequency (every four days) are preliminary, and there are no estimates of spawning duration of wild American shad. As a result, annual or total life-time fecundity for this species is presently inestimable. A critical assumption in estimates of annual or lifetime fecundity is that the number of oocytes is fixed at the beginning of the spawning season, and that there is no production of new yolked oocytes after spawning begins (HUNTER, LO, and LEONG, 1985). In our material, we observed a continuous size distribution of oocytes in maturing, hydrated and partially spent individuals, a trait characteristic of indeterminate fecundity in many fishes (HUNTER and MACIEWICZ, 1985). Thus, American shad probably exhibit indeterminate fecundity. These findings suggest that previous estimates of annual or life-time fecundity reported for American shad may be inaccurate (CLIFT, 1872 ; MEEHAN, 1907 ; WALBURG and NICHOLS, 1967 ; CARSCADEN and LEGGETT, 1975b ; LEGGETT and CARCASDEN, 1978 ; WIGGINS et al., 1985). Batch fecundity, spawning frequency and spawning duration are unknown for 
most spawning populations along the U.S. Atlantic coast. These data are required to confirm hypotheses of latitudinal variation in total fecundity that form the basis for our present concept of reproductive ecology in American shad (LEGGETT and CARCASDEN, 1978).

Histological criteria allow for the determination of five easily identified maturity stages in American shad (maturing, hydrated/running ripe, partially spent, spent and resting). In paired comparisons of the results of microscopic and macroscopic classification of ripening and post-spawning females, we found that the two methods are not interchangeable. The greatest disagreement was observed in macroscopic determination of spent and partially spent gonads. Maturing and partially spent gonads were often confused, an error that could bias index-removal and change-in-ratio estimators. Thus, we recommend histological scoring of maturity stage, especially when accurate counts of ripening and spent fishes are required.

In our samples of partially spent American shad, the ratio of fresh to older POFs is variable and a relative indication of time since spawning. Spawning frequency can be estimated using the POF method (HUNTER and MACEWICZ, 1985) but samples of ovarian tissue from daily egg-taking activities (Table II) for American shad on the spawning grounds were not available. MYLONAS et al. (1995) observed a complex spawning cycle for captive females; two days of spawning followed by two days of no spawns or very low fecundity. To confirm the pattern described by MYLONAS et al. (1995) in wild populations, we would expect to see the following proportions of fresh and older POFs in a large sample taken daily on the spawning grounds : 1 (fresh POF) : 1 (fresh + older POF) $: 2$ (only older or no POFs). It is noteworthy that our preliminary estimate of spawning frequency (4 days) based on the hydrated-oocyte method of HUNTER and MACEWICZ (1985) encompasses the pattern observed by MYLONAS et al. (1995) but does not confirm it. The hydrated-oocyte method (100\% divided by the proportion of females that are hydrated) is a relatively crude approximation of spawning frequency that can not detect a complex pattern.

A reproductive cycle of American shad in the York river is depicted in Figure 6 . This concept is based on the observations reported here as well as recent studies of age and spawning history of the York river population (MAKI, HOENIG and OLNEY, in press). The annual spawning run consists of virgin fishes 3-7 years in age plus repeat spawners ( 4-10 years in age). American shad nine years and older are apparently rare in the York river system (NICHOLS and MASSMANN,1963 ; MAKI, HOENIG and OLNEY, in press). As maturing fish migrate $100 \mathrm{~km}$ up the estuary to the freshwater spawning grounds, ovary size increases. A multiple spawning cycle (hydration, ovulation and release of oocytes followed by 1-3 days of no spawning before a repeat in the cycle) of unknown duration ensues. In most years, spawning begins in late February and ends in early June (HILDEBRAND and SCHROEDER, 1928 ; BILKOVIC, OLNEY and HERSHNER, in press). Post-spawning fish leave the spawning grounds beginning in mid-April and most of these (approximately $70 \%$ ) are partially spent with ovaries that weigh 1-8 times those of spent fish. Thus, it appears that the potential annual fecundity of most female American shad is not realized during the spawning season on the York river system. Furthermore, partially spent ovaries contain energy reserves in the form of protein and lipids that could be recovered by resorption of un-spawned yolked oocytes. Upstream spawning migrations are energetically expensive, and tissues where energy is spared could presumably be used to enhance recovery from anadromous migration (LEONARD and MCCORMICK, 1999). Energy reserves in partially spent ovaries could augment somatic energy sources and enhance survival as post-spawning females in the York river re-enter the ocean. Since partially spent fish may have a greater potential for energy savings than spent fish, we hypothesize that partially spent fish have a greater chance than spent fish to become repeat spawners in subsequent years. These processes require further study. 


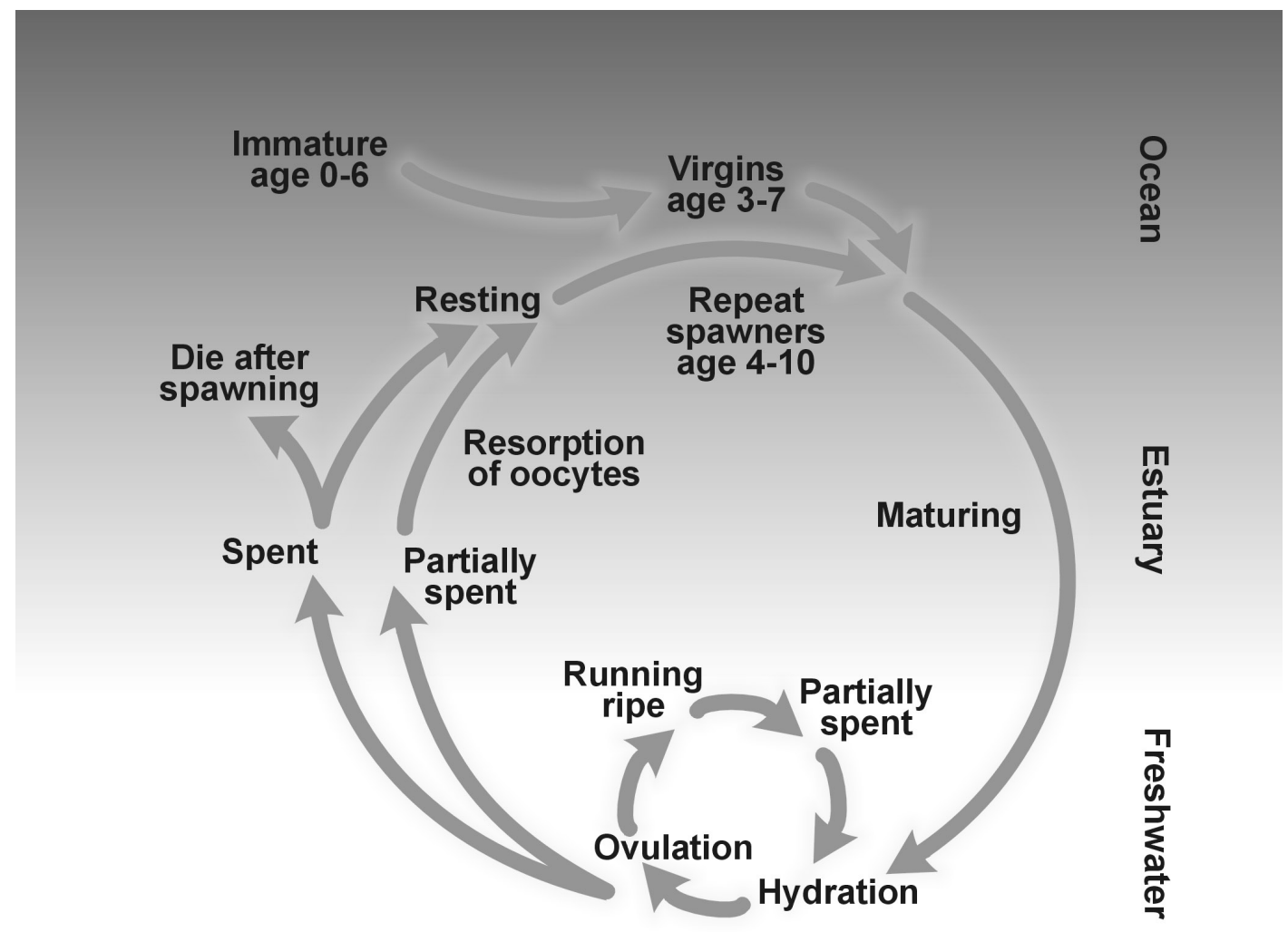

\section{Figure 6}

The reproductive cycle of female American shad in the York river, Virginia.

\section{Figure 6}

Le cycle de reproduction de l'alose américaine dans la rivière York, Virginia, USA.

Differences in the predictability of the reproductive environment, through its influence on juvenile mortality, are believed to regulate latitudinal patterns in life history strategies of anadromous fishes (LEGGETT and CARSCADDEN, 1978). Rapid drops in water temperature produced by the passage of cold fronts during the spawning season significantly decrease egg production, hatching success, growth, and survival of larvae (GLEBE and LEGGETT, 1981 ; SECOR and HOUDE, 1995 ; RUTHERFORD and HOUDE, 1995 ; MCGOVERN and OLNEY, 1996). When reproductive success is unpredictable, iteroparity may increase population stability and lower the chances of extinction (LEGGETT and CARSCADDEN, 1978). On a shorter time scale but by corresponding argument, multiple or batch spawning by an individual female throughout a single season of variable environmental conditions enhances the opportunity for hatching success and cohort survival. Batch spawning has important ecological implications since fishes can spread gametes over a large spatio-temporal scale, thereby increasing the chances that progeny will encounter salubrious conditions. Since both semelparous and iteroparous populations of American shad are batch spawners, populations exhibiting either life history strategy are resilient to unpredictable reproductive environments. 


\section{ACKNOWLEDGEMENTS}

We thank Wm. ROUMILLET, C. WENNER, K. LIMBURG, G. MOSER, G. WHITE, K. MAKI, D. BILKOVIC and J. WALTER for helpful comments and suggestions during the course of this study. Cooperating fishermen were D. GREEN, R. KELLUM, R. BUSH, G. MILES, T. CUSTALOW and C. CUSTALOW. We appreciate the special assistance of F. LARKIN. T. GUNTER (Virginia Department of Game and Inland Fisheries, Ashland, Virginia, USA) provided the daily catch data of hydrated females. We obtained comparative material with the assistance of J. McCORD (South Carolina Department of Natural Resources) and R. THOMASIAN (Massachusetts Division of Fisheries and Wildlife). This research was funded by the Wallop-Breaux Program of the U.S. Fish and Wildlife Service through the Marine Recreational Fishing Advisory Board of the Virginia Marine Resources Commission (Grant Numbers F-116-R-1 and F-116-R-2), and by the Anadromous Fish Conservation Act, Public Law 89-304 (Grant-In-Aid Project AFC-28, Grant Number NA86FA0261 and Project AFC-30, Grant Number NA96FA0229) from the National Marine Fisheries Service. This is contribution number 2,362 of the Virginia Institute of Marine Science, College of William and Mary.

\section{BIBLIOGRAPHY}

ATLANTIC STATES MARINE FISHERIES COMMISSION (ASMFC), 1999. Amendment 1 to the Interstate Fishery Management Plan for shad and river herring. ASMFC Fishery Management Rept., 35, 1-76.

BENGEN G., KUGLER J., PEQUIGNOT J., 1991. Etude des ovocytes d'Alosa alosa L. (Clupeidae) au cours de sa migration anadrome en Garrone. Cybium, 15, 229-238.

BENTZEN P., BROWN G.G., LEGGETT W.C., 1989. Mitochondrial DNA polymorphism, population structure, and life history variation in American shad (Alosa sapidissima). Can. J. Fish. Aquat. Sci., 46,1446-1454.

BIGELOW H.B., SCHROEDER W.C., 1953. Fishes of the Gulf of Maine. U.S. Fish. Wild. Serv. Fish. Bull., 53, 1-577.

BILKOVIC D.M., OLNEY J.E., HERSHNER C.H., in press. Spawning of American shad (Alosa sapidissima) in the Mattaponi and Pamunkey rivers, Virginia. Fish. Bull.

CARSCADDEN J.E., LEGGETT W.C., 1975a. Meristic differences in spawning populations of American shad, Alosa sapidissima : evidence for homing to tributaries in the St John river, New Brunswick. J. Fish. Res. Board Can., 32, 653-660.

CARSCADDEN J.E., LEGGETT W.C., 1975b. Life history variation in populations of American shad, Alosa sapidissima (Wilson), spawning in tributaries of the St. John river, New Brunswick. J. Fish. Biol., 7, 595-609.

CLIFT W., 1872. Shad culture. Trans. Amer. Fish. Soc., 1, 21-28.

DAWE E.G., HOENIG J.M., XU X., 1993. Change-in-ratio and index-removal methods for population assessment and their application to snow crab (Chionoecetes opilio). Can. J. Fish. Aquat. Sci., 50,1467-1476.

DEMARTINI E.E., FOUNTAIN R.K., 1981. Ovarian cycling frequency and batch fecundity in the queenfish, Seriphis politus : attributes representative of serial spawning fishes. U.S. Fish. Bull., 79, 547-56.

GLEBE B.D., LEGGETT W.C., 1981. Latitudinal differences in energy allocation and use during the freshwater migrations of American shad (Alosa sapidissima) and their life history consequences. Can. J. Fish. Aquat. Sci., 38, 806-819.

HILDEBRAND S.F., SCHROEDER W.C., 1928. Fishes of Chesapeake Bay. Bull. U.S. Bureau of Fisheries, 43 (1), 1-366.

HOENIG J.M., MORGAN M.J., BROWN C.A., 1995. Analysing differences between two age determination methods by test of symmetry. Can. J. Fish. Aquat. Sci., 52, 364368. 
HOENIG J.M., POLLOCK K.H., 1998. Index-removal methods. Encyclopedia of Statistical Sciences Update, KOTZ S., READ C.B., BANKS D.L. (Eds.), Vol. 2, 342-346, John Wiley and Sons, Inc., New York.

HUNTER R.H., MACEWICZ B.J., 1985. Measurement of spawning frequency in multiple spawning fishes. NOAA Tech Rept. NMFS, 36, 79-94.

HUNTER R.H., LO N.C.H., LEONG R.J.H., 1985. Batch fecundity in multiple spawning fishes. NOAA Tech Rept. NMFS, 36, 67-77.

LAHAYE J., 1960. Croissance et maturation des ovocytes chez la forme totalement adaptée aux eaux douces de l'alose marocaine (Alosa alosa Linné). Rev. Trav. Inst. Peches marit., 24, 499-511.

LEHMAN B.A., 1953. Fecundity of Hudson river shad. U.S. Fish. Wildl. Serv. Res. Rpt., 33, $1-8$.

LEGGETT W.C., CARSCADDEN J.E., 1978. Latitudinal variation in reproductive characteristics of American shad (Alosa sapidissima) : evidence of population specific life history strategies in fish. J. Fish. Res. Brd. Canada, 35, 1469-1478.

LEONARD J.B.K., MCCORMICK S.D., 1999. Effects of migration distance on whole-body and tissue-specific energy use in American shad (Alosa sapidissima). Can. J. Fish. Aquat. Sci., 56, 1159-1171.

LOWERRE-BARBIERI S.K., BARBIERRI L.R., 1993. A new method of oocyte separation and preservation for fish reproduction studies. U.S. Fish. Bull., 91, 165-170.

MAKI K.L., HOENIG J.M., OLNEY J.E., in Press. Estimating proportion mature when immature fish are unavailable for study, with application to American shad (Alosa sapidissima) in the York river, Virginia. North Amer. J. Fish. Management.

MCGOVERN J.C., OLNEY J.E., 1996. Factors affecting survival of early life stages and subsequent recruitment of striped bass on the Pamunkey river, Virginia. Can. J. Fish. Aquat. Sci., 53, 1713-1726.

MEEHAN W.E., 1907. The shad work on the Delaware river in 1907 and its lessons. Trans. Amer. Fish. Soc., 36, 105-113.

MELVIN G.D., DADSWELL M.J., MARTIN J.D., 1896. Fidelity of American shad, Alosa sapidissima (Clupeidae), to its river previous spawning. Can. J. Fish. Aquatic Sci., 43, 640-646.

MYLONAS C.C., ZOHAR Y., RICHARDSON B.M., MINKKINEN S.P., 1995. Induced spawning of wild American shad Alosa sapidissima using sustained administration of gonadotropin-releasing hormone analogue (GnRHa). J. World Aquaculture. Soc., 26, 240-251.

NICHOLS P.R., MASSMANN W.H., 1963. Abundance, age and fecundity of shad, York river, Va., 1953-1959. U.S. Fish. Wild. Serv. Fish. Bull., 1, 179-187.

NOLAN K., GROSSFIELD J., WIRGIN I., 1991. Discrimination among Atlantic coast populations of American shad (Alosa sapidissima) using mitochrondrial DNA. Can. J. Fish. Aquat. Sci., 48, 1724-1734.

OLNEY J.E., HOENIG J.M., 2001. Managing a fishery under moratorium : assessment opportunities for Virginia's stocks of American shad (Alosa sapidissima). Fisheries, 26 (2), 6-12.

POLLOCK K.H., HOENIG J.M., 1998. Change-in-ratio estimators. Encyclopedia of Statistical Sciences Update, KOTZ S., READ C.B., BANKS D.L. (Eds.), Vol. 2, 342346, John Wiley and Sons, Inc., New York.

ROBINS C.R., RAY C.C., DOUGLASS J., 1986. A field guide to Atlantic coast fishes of North America. Houghton Mifflin Co., Boston.

RULIFSON R.A., 1994. Status of anadromous Alosa along the east coast of North America, 134-158 in : COOPER J.A., EADES R.T., KLAUDA R.J., LOESCH J.G. (Eds.). Anadromous Alosa Symposium, Tidewater Chapter, American Fisheries Society, bethesda, Maryland, USA.

RUTHERFORD E.S., HOUDE E.D., 1995. The influence of temperature on cohort-specific growth, survival, and recruitment of striped bass, Morone saxatilis, larvae in Chesapeake Bay. Fishery Bulletin, 93, 315-332. 
SCOTT W.B., CROSSMAN E.J., 1973. Freshwater fishes of Canada. Fish. Res. Board Canada, 184, 1-966.

SECOR D.H., HOUDE E.D., 1995. Temperature effects on the timing of striped bass egg production, larval viability, and recruitment potential in the Patuxent river (Chesapeake Bay). Estuaries, 18, 527-544.

TALBOT G.B., SYKES J.E., 1958. Atlantic coast migrations of American shad. U.S. Fish. Wildl. Serv. Fish. Bull., 58, 473-490.

WALLACE R.A., SELMAN K., 1981. Cellular and dynamic aspects of oocyte growth in teleosts. Amer. Zool., 21, 325-343.

WALBURG C.H., 1960. Abundance and life history of shad, St. John's river, Florida. U.S. Fish. Wild. Serv. Fish. Bull., 177, 487-501.

WALBURG C.H., NICHOLS P.R., 1967. Biology and management of the American shad and the status of the fisheries, Atlantic coast of the United States. U.S. Fish. Wildl. Serv. Spec. Sci. Rept Fish., 550, 1-105.

WIGGINS T.A., BENDER T.R.J., MUDRAK A., KREMMEL J.R., 1985. The influence of rolling on the hatch of American shad eggs. Progr. Fish Cult., 46, 51-52. 
